\title{
Evolution of Electricity Metering Technologies in Nigeria
}

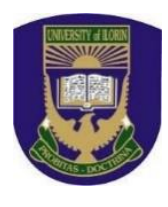

\author{
F. M. Dahunsi ${ }^{*}$, O. R. Olakunle ${ }^{2}$, A. O. Melodi ${ }^{2}$ \\ ${ }^{1}$ Department of Computer Engineering, Federal University of Technology, Akure, Nigeria. \\ ${ }^{2}$ Department of Electrical \& Electronics Engineering, Federal University of Technology, Akure, Nigeria.
}

ABSTRACT: Advancement in technology has continuously driven the evolution of metering devices and infrastructure in the world and has resulted in more accurate and user-friendly devices equipped with customer interaction interfaces. The evolution of metering technology in Nigeria arose with the unbundling of the National Electric Power Authority (NEPA) but have not progressed smoothly and successfully despite the implementation of various reforms and policies in the Nigerian electricity industry. The persisting problems in the electricity distribution system such as energy theft, vandalism, energy wastage, high line losses can be overcome by the deployment of appropriate metering infrastructure. In the second quarter of 2020, the Nigerian Electricity Regulatory Commission revealed that the total registered customers and total metered customers are 10,516,090 and 4,234,759 respectively leaving a metering gap of 59.73\%; after 124 years of commercial electricity availability in Nigeria. This paper discusses Nigeria's metering history and the challenges encountered in the transition of policies, technologies and government reforms. The paper also proposes the way forward to a successful transitioning into a smart distribution grid.

KEYWORDS: Electricity meters, metering infrastructure, NERC, smart grid, distribution system

\section{INTRODUCTION}

Electricity was introduced in Nigeria in 1896, fifteen years after its introduction in England (Onochie, Egware, and Eyakwanor, 2015), and electricity metering is directly linked with the production and distribution of electricity on a commercial basis (Sule, 2010; Utazi and Obuka, 2014). According to Ayamolowa et al., (2019) and Okoro and Chikuni (2007), the various reforms and restructuring to improve power supply brought about the constitution of the Nigerian Electricity Supply Company ((NESCO) in 1929, which was succeeded by the Electricity Corporation of Nigeria (ECN) and the establishment of Niger Dams Authority (NDA) in 1962. The ECN and NDA were later merged in 1972 to form NEPA, with a mandate to provide electricity across Nigeria (Oluwatoyin, Odunola, and Alabi, 2015). After 40 years of unsuccessful management of electricity generation, transmission, and distribution in Nigeria, it was transitioned to the Power Holding Company of Nigeria (PHCN) by the electricity reform of 2005, set up before the privatization of the sector (Diji, 2013). The privatization of PHCN was premised on adequate and reliable power supply according to Osigwe and Onyimadu (2018), which was then unbundled to six Generating companies (GENCOs), One Transmission Company (TCN), and eleven Distribution companies (DisCos) and eventually privatized in 2013 except for TCN that was placed under a contract agreement (Idowu et al., 2019).
These companies were responsible for the functions relating to the generation, transmission, distribution, trading, and bulk supply as well as resale of electricity (National Technical Working Group Report, 2009). The duty of regulation is performed by the National Electricity Regulatory Commission (NERC) under the Federal Ministry of Power. According to Ogbuefi et al. (2019). Fifteen years after the Power Sector Reform Bill, electricity status in Nigeria is far away from the target. As shown in Figure 1, the total number of registered customers is just above 10 million in a country with a population of about 200 million people. Only about 5\% of the population of Nigeria are registered customers as inferred from Figure 1 and these are supplied with about $9 \mathrm{MWh}$ of electricity which is largely inadequate. This has led to a spate of power outages, erratic and largely unavailable power supply.

In evaluating the performance of the Nigerian electricity industry in place of the various reforms initiated, Oseni (2012) opined that a radical reform process that prioritizes electricity user welfare is needed. However, these restructuring and reforms have not resulted in a reliable power supply (Unachukwu, 2010). This reform has nevertheless contributed in no small measure to the evolution of metering devices and infrastructure in a bid to overcome the inherent problem of electricity theft which has bedevilled the distribution network (Nwokoye, et al., 2017). According to (Iloh, 2020) and Ayamolowo et al.2019)., the electricity metering of consumers in the distribution network is vital for efficient and reliable 
system delivery, resulting in attracting investors to the sector and encouraging customers to pay for electricity utilized. Therefore, the distribution companies must prioritize metering as the costs of service reflects on the consumers' utility bill (Orovwiroro, 2019).

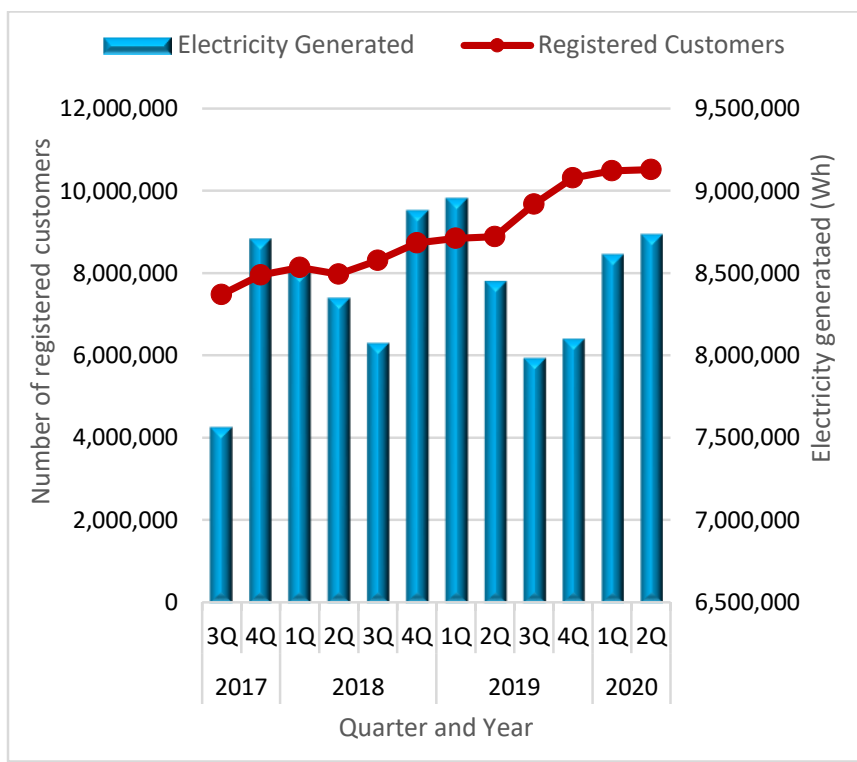

Figure 1: Electricity generation vs. number of registered customers for four years in Nigeria.

Overview of the metering system in Nigeria has been extensively discussed in the literature. Electricity meters are divided into three basic categories: electromechanical meter, electronic meter, and smart meter. Figure 2 shows some samples of electricity meters in Nigeria. In a study conducted by Abdulwahab (2009), it was observed that the electromechanical meters in use in Nigeria are obsolete and require replacement. In Oyedepo (2012), the metering system in Nigeria was regarded as inefficient and does not encourage payment by the consumers. While Okafor et al. (2017), regarded Electricity metering in Nigeria as costly and inflexible. The use of such meters has resulted in poor customer response to bill payment because of perceived outrageous and estimated billing. The inherent problems of electromechanical meters according to Ndinechi et al. (2011), that makes it unsuitable for smart grid application include calibration error/loss of calibration due to age, meter orientation problem, no user-friendly display, and no communication interface capability with an external device. These associated problems bring about the replacement of electromechanical meters with electronic meters (Islam, et al., 2012).

The benefits of implementing electronic meters include low power consumption, higher accuracy, temperature independence, storage facility, remote communication, and security. Specifically, Orukpe and Agbontaen (2013) indicated that the introduction of prepaid meters was aimed at eliminating estimated billing by the utility and it is observed to have had a positive impact on electricity consumption (Ajenikoko and Adelusi, 2015). Oseni (2015) concluded that the elimination of estimated billing increases the willingness of the majority of electricity users to accept the use of prepaid meters. Moreover, electricity prepaid meters have other advantages aside from eliminating estimated billing, which includes its use to curb electricity theft (Dike et al., 2015) and to profile actual power utilized. (Ogbuefi et al., 2019). However, the prepaid meters are not without disadvantages, which according to Aniedu et al. (2017) include a gross deficiency in solving problems like remote monitoring and control, energy theft, and energy losses amongst others. However, Amhenrior (2018) posits that prepayment meters in Nigeria have some level of smartness but this has not been completely harnessed to benefit both the consumer and the utility. The present technology of prepaid meters in Nigeria according to Samita and Devidas, (2018) uses the keypad technology while the more recent meters deployed are capable of two-way communication, an essential requirement for smart meters.

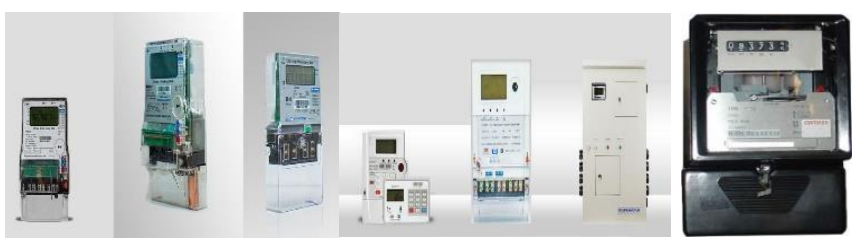

Figure 2: Samples of electricity meters available in Nigeria.

Smart metering devices are more modern than prepaid meters and can be used to eliminate energy theft, to achieve remote monitoring and control due to their capability for a twoway communication system (Fidelis et al. 2019). As an energy management system to solve the problem of energy theft and wastage in the distribution system (Akpan et al., 2019). Makanjuola et al., (2019) indicate that the primary objective of the smart meter is for the reduction of energy consumption. The use of smart meters embedded with prepaid functionality has resulted in a decline in the use of prepaid meters. Furthermore, smart meters integrated with a home display help to create awareness on the energy usage of the consumer thereby encouraging energy conservation (Niyonteze, Zou, and Osarumwense, 2019). The advantages of smart meters also include high metering accuracy and reduced power outage which leads to increased revenue collection (Onohaebi and Omorogiuwa, 2014).

In brief, smart meters can be used to achieve remote meter reading, energy consumption awareness both for the utility and customers, the introduction of innovative tariff system, eliminate theft and non-payment of electricity by the customers. It also determines the location of outages remotely (Chiatula et al., (2019), Chukwuorji, et al., (2019). It is however observed that the smart meter when breached by an experienced technician may fail to report the incident of tampering (Olaoluwa, 2017). Table 1 presents a comparison of electromechanical, electronics, and smart meters based on eight evaluation criteria. Smart meters outperform the others presented.

Pakistan is also a developing country struggling to have a sustainable power sector, the analysis carried out by (Qazi et al., 2020) on the Pakistan power system revealed that there was a continuous increase in electricity demand under the 
conventional strategy that has resulted in electricity shortages. Pakistan will be able to achieve a sustainable power sector if it succeeds in managing the future increase in electricity demand effectively. Among available energy conservation and management techniques, prepaid metering is one of the most effective techniques to manage the increasing electricity demand.

Table 1: Comparison of metering technologies.

\begin{tabular}{|c|c|c|c|}
\hline \multirow[t]{2}{*}{ Criteria } & \multicolumn{3}{|c|}{ Electricity Meters } \\
\hline & $\begin{array}{l}\text { Electrome- } \\
\text { chanical }\end{array}$ & Electronic & Smart \\
\hline Customer interaction & $\begin{array}{c}\text { Very } \\
\text { limited }\end{array}$ & Limited & Extensive \\
\hline Ability to monitor & Blind & Blind & $\begin{array}{c}\text { Self- } \\
\text { monitoring }\end{array}$ \\
\hline $\begin{array}{l}\text { Restoration following } \\
\text { disturbance }\end{array}$ & Manual & Manual & Self-healing \\
\hline Flow of information & One-way & One-way & Two-way \\
\hline Power flow control & Limited & Limited & Automated \\
\hline Energy conservation & Low & Medium & High \\
\hline Distribution line losses & High & Medium & Low \\
\hline Billing & Flat rate & Flat rate & $\begin{array}{l}\text { Real-time } \\
\text { pricing }\end{array}$ \\
\hline
\end{tabular}

The electricity meter is a vital device that quantifies the energy consumption of respective electricity user and this determines the cost of consumption based on the tariff system applied. Different electricity meters can be used for this purpose based on the metering technology available. This paper aims to review various metering devices that have been deployed to overcome identified problems associated with the distribution system in Nigeria and also to determine the status of electricity metering in Nigeria.

This review paper is organized as follows: in Section II, research questions are highlighted. In Section III, the method applied for the reviewed papers collection procedure is explained. A detailed literature review on past studies related to trends in electricity meter evolution in Nigeria and the status of electricity metering in Nigeria is provided in Section IV. Section V, discusses the impact of lack of electricity meters on some sections of Nigeria's economy. While issues, challenges, and a way forward are discussed in Section VI. Conclusions are drawn in Section VII.

\section{ELECTRICITY METER EVOLUTION IN NIGERIA}

Electric meters are developed for measurement and recording of energy consumed by consumer units. Information derived from electric power meters are traditionally employed for systems planning, operation management, and consumers' billing (Ugonna, Ademola, and Olusegun, 2018; Dike, Ogu, Chukwuchekwa, and Dike, 2017).

\section{A. The Advent of Electromechanical Meter}

Metering in the Nigerian electricity grid before the year 2005 relies heavily on the electromechanical meter which uses a spinning dick. Energy consumed is manually read monthly by utility personnel to bill customers. Generated bills are again distributed manually before the customer can then approach local branch offices in their neighbourhood for payment. This process is archaic, inefficient, unreliable, and time-consuming.
Such a process encourages estimated billing which eventually resulted in customer dissatisfaction, energy and financial losses to the utility companies. No accurate data of metered customers existed in this era of the metering system (Matthew et al., 2018).

\section{B. Introduction of Electronic Meters}

The transition of National Electric Power Authority (NEPA) into Power Holding Company of Nigeria (PHCN) took place in 2005. One of the many things it led to is the gradual replacement of electromechanical (post-paid) meters with electronic (prepaid) meters, because only few electricity consumers had access to it at inception (Arawomo, 2017). The unbundling of the Power Holding Company of Nigeria (PHCN) in 2013 also led to the advent of various pre-payment meters by the various distribution companies (Ejumudo and Ejumudo, 2014). However, according to (Aliu, 2020), the use of prepaid meters has been introduced in Lagos, Nigeria since the late 1990s with few households having access to it. The Key-type electronic prepaid meters were introduced in Nigeria in 2005 and later the smart card-type prepaid meters were introduced (Mankanjuola et al., 2015). The prepaid meters were distributed with no initial financial obligation but the cost of owning one is incorporated into the credit unit purchased; and thus, permitting gradual payment for the meter.

NERC's "Credited Advance Payment for Metering Implementation" (CAPMI) policy encourages electricity consumers to gradually pay for electricity meters, the meters were then supplied and installed after full payment. By 2016, there were 251,531 meters supplied through the CAPMI scheme out of the 403,255 total meters installed in about two years (Udo, 2016). CAPMI scheme collapsed in November 2016 due to a lack of commitment from the distribution company. However, NERC approved another initiative on the 8th of March 2018 called "Meter Asset Providers" (MAP) policy to further assist with bridging the metering gap (NERC, 2018). In the new scheme, third-party investors were allowed to supply meters to electricity consumers that have been enumerated by respective DisCos. Prepayment meters capable of remote credit top-up were introduced in 2019 to eliminate the need to physically access an electricity vending machine. Komolafe and Udofia (2020) in their study on inadequate metering in Nigeria posits that the metering devices being deployed should be capable of supporting the smart grid. Figure 3 presents a summary of metering facilities in the Nigeria distribution system.

The transition into using electronic power meters in Nigeria is accompanied by increased development of metering technology, various innovations were proposed by researchers to improve electricity metering in Nigeria. There are numerous published researches on the design of electricity meters curbing of electricity theft, billing system, smart distribution among others. A study into the design of an automated electricity metering system was conducted by Akwuiwu et al., (2018), the meter was capable of remote configuration and data acquisition. In a similar study, a metering system capable of remote prepaid or post-paid configuration enabled with a lowcost SMS two-way communication was designed and 

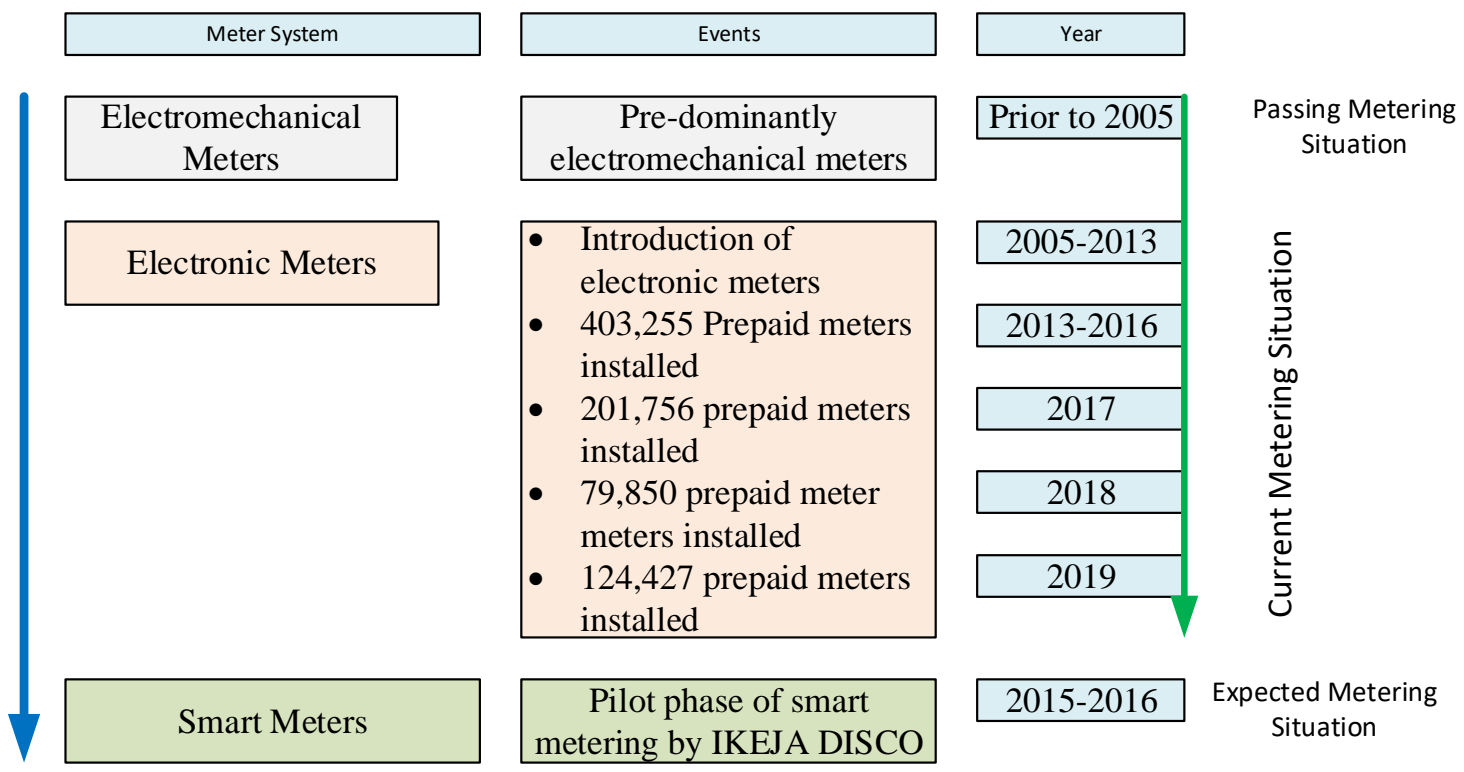

Figure 3: Summary of metering in the Nigeria distribution system.

implemented by Matthews et al., (2018). The design of a single-phase electricity meter capable of detecting and reporting tampering was proposed by Amhenrior et al., (2017) whereas a GSM-based prepaid meter was designed by Dike et al., (2015), to overcome the problem of electricity theft. The use of cost-effective IoT-based theft detection and prevention system was proposed by (Ogu and Chukwudebe, 2017) and a prepaid metering system with real-time monitoring and capability to detect energy theft was designed by Somefun et al., (2019). A system for the detection of electricity theft for prepaid meters was developed by Omijeh et al., (2012). However, it is noteworthy that electricity theft is aggravated because electricity consumers are not properly and appropriately metered (Shokoya and Raji, 2019).

Importation of electricity meters has long been the only means of providing metering devices in Nigeria. With the privatization of the industry, private investors' participation in the provision of metering devices has resulted in the establishment of various metering companies in Nigeria. Some companies are capable of local production of electricity meters, although local meter production is yet to achieve $100 \%$ local content. Local manufacturers are already working towards achieving this feat. The certified meter manufacturers in Nigeria are Elsewedy Electric Nigeria, Momas Electricity Meters Manufacturing Company (MEMMCOL), Uni-Star Hitech Nigeria, Electricity Meter Company Nigeria (EMCON), and MOJEC International (Smart Energy International, 2014).

\section{Smart Meters/Advanced Metering Infrastructure in Nigeria}

The National Electricity Regulatory Commission (NERC) has stipulated policies and regulations to achieve smart metering in the distribution system (Okoye, (2014),, Okoro and Chikuni, (2007). Pilot studies have been carried out by some distribution companies to experiment with the use of smart meters in Nigeria. This is done to understand what it will take to achieve transitioning from prepaid meters to smart meters. Presently, electricity usage data obtained is only used for billing purposes. The implementation of this NERC policy will result in a smart grid that delivers electricity to consumers using digital technology for continuous monitoring and optimization of the distribution system (Elizabeth et al., (2018).

The billing system which directly correlates with the meter type has also evolved. It was reported in a study by Ebem et al., (2018) that manual billing systems, estimated billing systems, and prepaid billing systems are the available billing system in Nigeria, although smart metering billing has been proposed. The billing system employed by NEPA is predominantly the post-paid system while PHCN introduced the prepaid system but the DisCos still use the post-paid (analogue) and the prepaid billing system simultaneously (Utazi and Obuka, 2014). One of the controversies between the DisCos and the consumers since inception, is the inappropriate billing system due to arbitrariness in determining customers' energy consumption (Anyaehie et al., 2018). The benefits of the prepaid billing system include improving cash flow, eradication of estimated billing, and control of energy usage among others (Ogbuefi et al., 2019).

A system aimed at resolving the problem of estimated billing which has been a contentious issue in the Nigeria electricity sector was proposed by Adetokun et al., (2018). The system was able to determine the amount to be paid by unmetered customers because of inadequate electricity meters by the electricity utility company. An electricity payment system was also developed using a web-based LUHN algorithm for prepayment electricity purchase to overcome the problem associated with token purchase at the utility (Jonathan et al., 2018). A billing system suitable for the multi-tenanted corporate building was analyzed by Arimoro et al., (2019) while a business framework using cloud computing and business intelligence to provide a better billing system was developed by Usman-Hamza and Salau-Ibrahim (2016). 
The Nigerian electricity grid must be preparing for inevitable trends observed all over the world. Two of such imminent trends are considered hereunder:

\section{1) Renewable Energy Penetration}

The world is turning towards the high penetration of renewable energy sources in the electric grid. The implementation of smart meters in the Nigerian electricity grid will be essential for the maximization of a flexible grid. With smart meters, utilities can accurately determine the behavior of consumers, regulate generation and transmission as at when due. Consumers under this situation can also regulate energy consumption since they would have a measure of control over their energy consumption (Javier et al., 2016).

\section{2) Growing Penetration of Electric Vehicles}

According to Global EV outlook 2020, electric vehicle sales reach 2.1 million in the year 2019, an indication of the increasing penetration of electric vehicles in the world (EV Volume, 2021). The interaction of EV with the grid cannot be effective without the use of smart meters. The implementation of advanced metering infrastructure (AMI) is a needed step to get the Nigerian electric grid ready for the imminent penetration of EV into the power grid. Efforts should be made for the implementation of smart meters in the place of the present electronic prepaid meters being deployed in the country.

\section{Status of Electricity Metering in Nigeria}

According to Utazi and Obuka, (2014), the procurement of meters was centrally coordinated by NEPA and continued with the PHCN, but with the power sector reform of 2005 and the unbundling of PHCN, the distribution companies (DisCos) can independently procure and install meters for their customers. Although, the unbundling of the electricity sector in Nigeria anticipates that the electricity companies should introduce modern and accurate metering systems with reliable communication facilities to measure and record energy production and utilization as stipulated in the Nigerian Metering Code-version 02, (subsection 1.2.2). The metering technology specified in the code for the distribution system are:

i. static/electronic meter - electronic credit meter

ii. prepayment metering system - smart card meter and split type prepayment dispenser

iii. Automatic meter reading system (AMR) prepayment and credit type meters

The vision of privatization to metering electricity users has not been met, several years down the lane, the complaints about estimated billing persisted. The second-quarter report of 2019 by NERC stated that there are 8,881,443 registered active electricity users in Nigeria, out of which $3,881,443$ users $(57.08 \%)$ are without metering devices. These unmetered customers' energy usage charges are estimated by the utilities (Adebulu, 2020). NERC's second quarter report of 2020, revealed that the total registered customer and total metered customer are 10,516,090 and 4,234,759 respectively leaving a metering gap of $59.73 . \%$. This indicates an increase of $2.65 \%$ in the metering gap within a year, though there is a considerable increase in both the number of the registered and metered customers. Figure 4 shows a summary of the metering status of the country for the past three years, data was gathered from NERC's quarterly reports (NERC, 2017-2019).

The meter supply scheme was conceived in 2011 but came into effect in January 2015, and five years down the lane, electricity consumers have not fully benefited from the various meter intervention schemes, therefore efforts should be intensified to provide prepaid meters (Okolobah and Ismail, 2013). The prices of prepaid meters vary from one DISCO to another under the CAPMI policy but NERC has issued a harmonized price under the MAP policy with a single-phase meter to cost $\$ 36,991.50$ and a three-phase meter to cost $¥ 67,055.85$. It is observed that under the MAP program initiated in 2018 , only $4 \%(33,000)$ of the total application made for meters were supplied and $61 \%$ of the total complaints received by NERC were on metering and billing (Bello, 2019). Due to changes in macroeconomic parameters, NERC has approved the upward review of meters with a single-phase meter to cost $\$ 44,896.17$ and a three-phase meter to cost 82,855.19 exclusive of Value Added Tax (VAT) as contained in the Meter Asset Provider Regulations (NERC, 2020). Figure 5 presents the metering status of the DisCos as of Q4 of years 2017, 2018 and 2019 with Benin Disco having the most coverage.

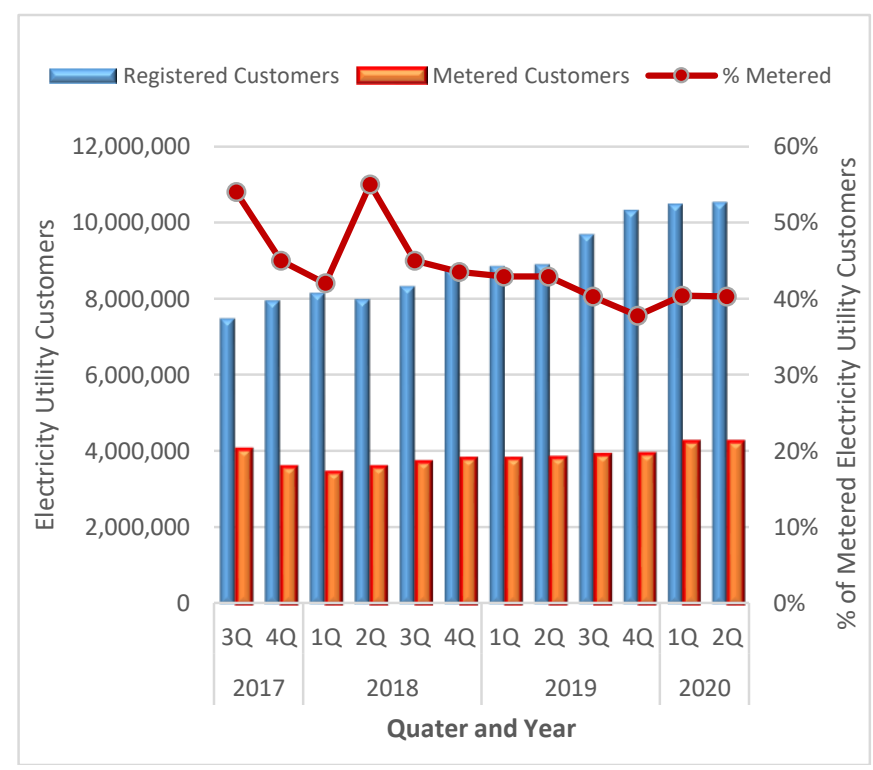

Figure 4: Metering status of Nigeria's electricity utility customers.

\section{E. The global electricity metering trend}

Kambule et al. (2018) observed in an extensive study that the global electricity metering trend from conventional metering to prepaid metering can be categorized as persisting and emerging trend. The study reveals that prepaid metering has been persistent metering technology in use by most countries while the emerging trend is in smart prepaid metering which is gradually supplanting the conventional prepaid system due to the functional convenience of smart meters. A study on the prepaid metering trend by Qazi et al. (2020), indicates that the United Kingdom is the first developed country that introduced prepaid meters in the 1970s while the 


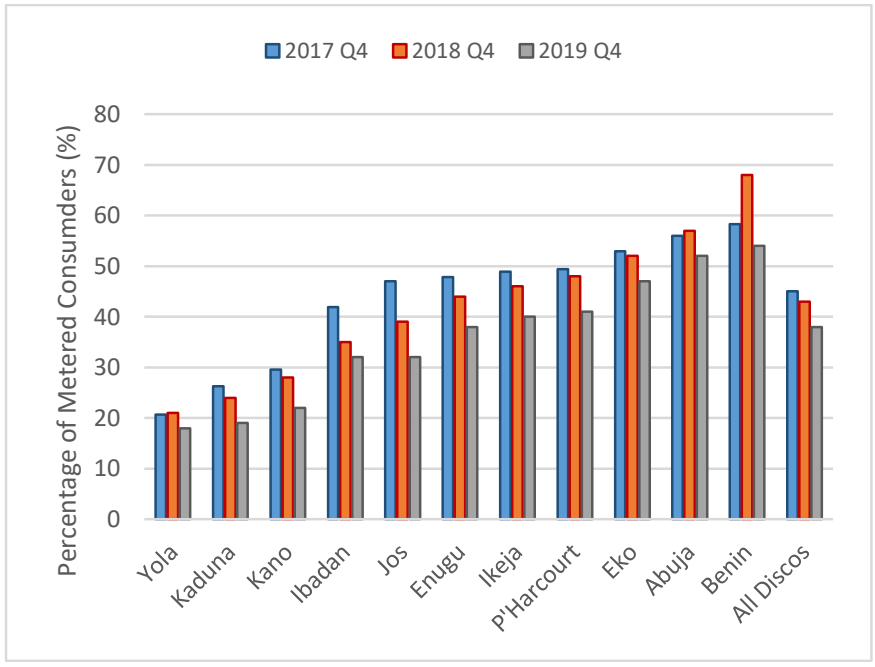

Figure 5: Metering status of the DisCos for Q4 of years 2017 - 2019.

United States introduced them in the 1990s with Australia introducing them in 1997. South Africa is the first developing country to introduce prepaid meters in 1988 while it was introduced in Nigeria and India in 2005. In research by Scully (2019), it was reported that $14 \%$ of all meters globally are smart meters, and the adoption of smart meters in Europe and North America is at a similar rate with an estimated penetration rate of $30-40 \%$ with Italy, Sweden, Finland and Netherland reaching $80 \%$ of target penetration rate.

The United Kingdom in 2015 started the implementation of smart meter deployment to reach all households in 2020 to achieve its energy efficiency policy that will encourage citizens to install energy-saving home appliances. In achieving this target, problems that might cause delays such as technical problems, interoperability standards, delayed communication infrastructure, and reluctance to improve transparency were identified with measures put in place to overcome them. The United Kingdom government also set up a governmental body to control and oversee Information Technology infrastructure for smart meter roll-out (Murphy, 2016).

In a review by Bimenyimana and Asemota, (2018), it was reported that Thailand, a developing nation in 2015 put in place policies for the 2018 smart grid roll-out, and the country invested in building energy management systems in 2017 towards the roll-out of smart grid pilot launch. Large scale smart meter roll-out is being undertaken in Asia- Pacific while Africa is still at the early stage of smart meter rollout with a penetration rate of below 5\% with Nigeria and South Africa being the front runner at the pilot stage. It is however observed that the main barrier to the adoption of smart metering in Africa is lack of funding and government initiatives coupled with inadequate infrastructure due to obsolete technologies when compared to the US, Europe, and Asia-Pacific.

\section{IMPACT OF LACK OF ELECTRICITY METERS}

According to Usman et al., (2016), fair and effective metering and billing are reported as one of the interconnected determinants of consumer protection. In this section, the impact of lack of electricity meters will be discussed with a focus on customer satisfaction, economic growth, and development, small and medium scale enterprises (SMEs), government, utility provider, and electricity regulator.

\section{A. Customer Dissatisfaction}

In a study to evaluate customer satisfaction on electricity consumption, Usman (2013) posited that customer satisfaction is used as a veritable tool for measuring organizational performance and relevance. The study concluded that the customers are not satisfied with the services of the DisCos. There has been a long-standing dissatisfaction with the use of the analogue meters due to estimated billing. Customer satisfaction is directly linked to service quality and delivery (Odunlami and Sokefun, 2018). According to Usman (2013), electricity consumer satisfaction can be examined on four indicators which are: product (electricity availability), service (customer relation), network (safety, reliability), and payment (payment facility, payment method, the accuracy of billing). In a study by Isola and Mesagan, (2017), electricity consumers are dissatisfied with exorbitant bills and poor service delivery which is a result of lack of electricity meters. Total complaints received for the fourth quarter of 2019 revealed that metering accounts for $23.37 \%$ while billing accounts for $27.13 \%$.

The NERC second-quarter report of 2019 stated that customer complaints centered on service interruption, poor voltage, load shedding, metering, estimated billing, disconnection, delayed connection, among others. It was also reported that complaints on metering and billing dominated customers' grievances and complaints over the years as presented in Figure 6 (NERC, 2017-2019). These complaints have led the government to initiate various meter supply schemes such as the previously discussed CAPMI and then MAP. The understanding of the journey made so far in the evolving scenario of the metering system in Nigeria will assist in identifying the metering solutions to be deployed that will yield the maximum benefit for both the utility and the electricity consumers.

\section{B. Low Economic Growth and Development and Underperformance of Small and Medium Scale Enterprises (SMEs)}

Electricity has been reported to be the basic driver of economic development (Emodi and Yusuf, 2015) and for an adequate standard of living (Oyedepo, 2012). Electricity consumption is directly related to the growth of a nation and forms the backbone of industrialization (David, 2018). It is reported that Nigeria's access to electricity is low despite having the largest economy in Africa in terms of GDP and population (Emodi and Yusuf, 2015). This lack of access to electricity harms productivity and limited economic opportunity available in Nigeria (Amakom and Nwogwugwu, 2012).

According to Oyedepo (2012), expensive and unreliable power is a problem to all sectors of the economy in Nigeria making businesses rely on electric generators to power their businesses thereby increasing considerably operating cost. This makes companies either close up or spend most of the profit made on the alternate power supply which adversely increases the prices of goods and services resulting in a high 


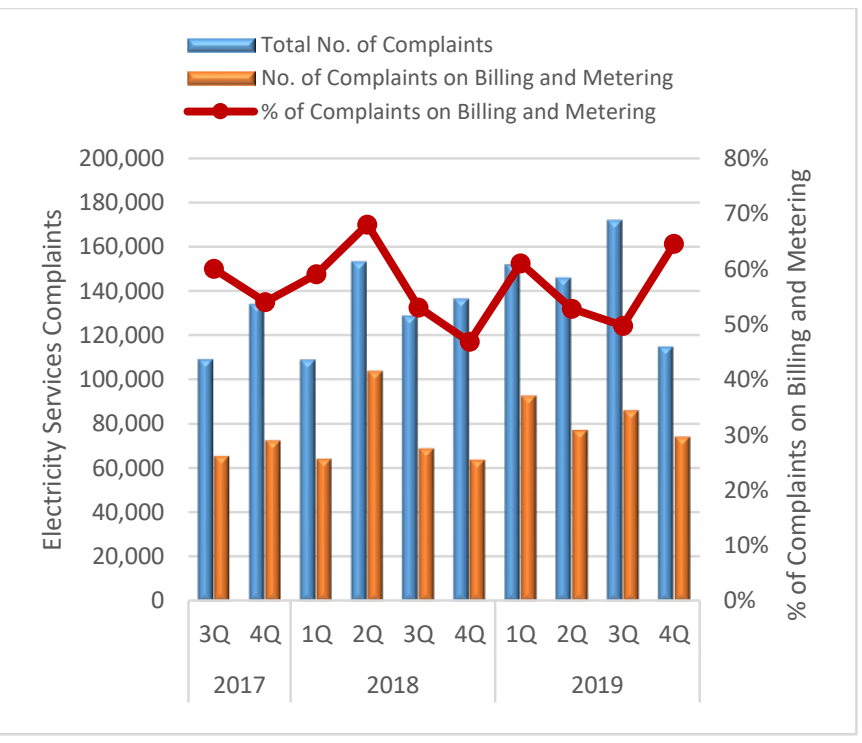

Figure 6: Electricity utility service customer complaints status.

cost of living in Nigeria (Jibril, 2017). The erratic power supply further causes malfunction or destruction of equipment and devices which leads to great financial losses. A good metering system will contribute to electric energy conservation and as a result, assist in making electric energy more available for an increased number of users.

\section{Unsustainable Government Subsidy on Electricity}

The Nigerian government NERC have advocated for electricity subsidy for the players in the power sector to reduce tariff hike and to give a fair return on investment. It is however observed that acceding to the request of subsidy and to prevent the implementation of the cost-reflective tariff has cost the government a huge amount of money in debt of over N500 billion by 2019 to the Distribution companies (PWC, 2019). It is however opined that continuous subsidy on electricity consumption by the government is unsustainable (Jeremiah, 2020). In the study by Monyei et al., (2017), it was concluded that with the current policies and existing infrastructure, the government will not achieve much considering the low hourly per capita income for Nigerians. The availability of electricity meters in prepaid mode will ensure revenue collection and end government subsidy on electricity consumption.

\section{Loss of Revenue by Electricity Utility providers}

Electric utilities lose huge revenue to electricity consumers because of the lack of electricity meters encouraging energy theft and high rate of non-payment of electricity bills but the provision of electricity meter is the only way to encourage and sustain regular payment of electricity (Fagbohun and FemiJemilohun, 2017). It is reported that non-paying electricity customer goes undetected because of the unavailability of electricity meters (Arowolo and Perez, 2020) while according to Okafor et al., (2017), the unmetered customers have resulted to riots, criticism, and threat against the utility staff because they are forced to pay electricity bill whether there is supply or not (Dada, 2014). Connivance between utility staff and the unmetered and indebted customer has taken a negative toll on revenue generation by the utility Adetoba et al., (2018). It is however reported that by installing a metering system, cash flow is improved, and bad debts are avoided Okafor et al., (2017). It is however observed that improving power reliability will increase revenue generation (Ogujor and Otasowie, 2010).

\section{E. Weak Electricity Regulatory Institution}

The Nigeria Electricity Regulatory Commission (NERC) has implemented various policies that have not achieved the set goals in bridging the metering gap. The failure of the CAPMI policy and now the poor implementation of the MAP scheme is a pointer that more is still needed to be done by the regulatory body who has made it mandatory for all DisCos to meter all electricity consumers. It is worthy to note that Idowu et al., (2019) regarded the electricity sector business environment as poorly regulated, there is a prevalence of indecent practices in the sector with the need for NERC to be proactive in addressing stakeholders concerns especially by making customers have access to prepaid meters. There is no wonder that it is reported that where there exists a weak regulatory institution, the reform will further hurt the intended beneficiaries (Idowu et al., 2019).

\section{IV.ISSUES AND CHALLENGES}

The issues and challenges observed with the phases of meter evolution and metering in Nigeria as observed in the pieces of literature are presented in this section.

\section{A. Framework and Policies}

According to European Union (2016), a policy framework is the institutionalized system of regulations that oversees the institutional and legal design of the regulatory system as well as the actual decisions made by the regulatory Authority (European Union, 2016). Nigeria has some electricity metering policy frameworks such as the National Electric Power Policy (NEPP) of 2001, the National Energy Policy in 2003, and the Electric Power Sector Reform (EPSR) Act of 2005 (ESI Africa, 2018). Specific to electricity metering are metering obligations of Distribution Companies (DisCos), Methodology for estimated Billing regulations of August 2012, Credited Advance Programme for Metering Implementation (CAPMI) of 2013, Order on Unauthorized Access, Meter tampering and Bypass in 2017, Smart metering regulation in 2017, Meter Asset Provider (MAP) in 2018, and the latest, a Consultation Paper on the Capping of estimated billing for Unmetered Electricity Customers.

NEPP 2001 and the National Energy Policy in 2003 focused primarily on optimizing the utilization of the nation's energy resources thereby vouching to provide reliable electricity to over three-fourths of the nation's population (Usman and Abbasoglu, 2014). However, the lack of an effective and efficient tariff system propelled the making of the EPSR Act of 2005 which mandated an efficient and effective cost-reflective tariff (Anosike, Dara, Ngwaka, and Enemuoh, 2017). EPSR catalysed an increase in power generation and ensured the adoption of the Multi-Year Tariff Order (MYTO) by Nigeria Electricity Regulatory Commission (NERC) (Ismail and Okolobah, 2013). Most of the metering 
specific regulations were marred by irregularities spanning overbearing of legal customers, electricity theft, and a large metering gap. However, according to the Nigerian Electricity Regulatory Commission (2018), MAP regulation was enforced on the 3rd of April, 2018 to (Nigerian Electricity Regulatory Commission, 2018):

i. give room for private investments,

ii. reduce, to the barest minimum, inaccurate billing estimates,

iii. encourage competitive and independent metering services, and

iv. hasten the closure of the nation's metering gap.

The breakthrough of this framework is the increase in the number of metered homes. Also, a significant number of illegal customers who were engaged in electricity theft in the form of illegal bypass were exposed (Alao, 2020). However, despite these numerous and enticing policies and many more efforts, problems and challenges still abound. Their numbers have resulted in "policy somersault" as different administrations tend to introduce different policies instead of enforcing the ones already made (Ismail and Okolobah, 2013). There is a lack of a well-thought-out policy framework and political commitment to enforce adopted policies. Lack of implementation of policies by the DisCos has also hindered the successful transition from electromechanical meters to electronic meters.

This work finds that policy frameworks have encouraged the deployment of advanced metering technology but the lack of adequate local meter production capacity will continue to adversely affect the deployment of modern metering devices, therefore, local production of low-cost metering devices should be aggressively pursued to make electricity meters accessible and affordable.

\section{B. Local Production of Electricity Meters}

Local production of meters involves manufacturing electricity meters locally. This is to ensure the availability of meters locally without much dependence on foreign products. Since 2015 which saw the breakthrough in ensuring locallymade meters are available, different companies have sprung up to compete in the market. However, production processes have been erratic and marred by a lack of funding. In the same vein, some DisCos preferred international products (Smart Energy International, 2014), hence the partial enforcement of MAP regulation which mandated that at least 3 out of 10 volumes of meters should be locally sourced (Nigerian Electricity Regulatory Commission, 2018). Production of electricity meters by indigenous companies has not been sufficient to bridge the wide metering gap and the small number of local meter manufacturers have hindered competitive pricing that will result in low cost of electricity meters. Metering technology that will bring about a drastic reduction in the prices of electricity meters should be encouraged.

\section{Affordability of Meters}

According to Eko Electricity Distribution Company PLC (EKEDC), the MAP framework's approved prices for singlephase and three-phase meters are $\$ 44,896.17$ and $\$ 82,855.19$ respectively (EKEDC, 2019). However, Benin Electricity
Distribution Company PLC (BEDC) (BEDC, 2018) pegged them at $\$ 24,832.00$ and $\$ 53,820.00$ respectively (BEDC Electricity Plc., 2018). 5\% Value Added Tax (VAT) was not included either was the recent naira devaluation accounted for (Alao, 2020). Even at those prices, they are still unaffordable to more than $40 \%$ of the Nigerian population which were estimated to live below the poverty line of $\$ 11,452.5$ monthly income by (National Bureau of Statistics, 2019). Since the unit cost of these meters is well over the estimated average Nigerian income, it is then unaffordable. It is estimated that over 100 million Nigerians earn 700 per day with $50 \%$ of the population living in extreme poverty (Odutola, 2019). The National Bureau of Statistics estimated that 82 million Nigerians live on less than $\$ 1$ a day in the report of poverty and inequality from September 2018 to October 2019. This staggering poverty level should be factored in to make electricity meters available and affordable for electricity consumers.

The cost of electricity meters produced locally is not affordable due to the high cost of operating a business in the country and also the cost of meters due to prohibitively high importation duties and processes, thereby discouraging meter purchase by electricity consumers. The government should make a special intervention in the electricity supply industry especially concerning metering because finance has been repeatedly echoed as a factor that has made metering electricity users impossible. The high cost of smart metering technology in comparison with prepaid metering has discouraged its roll-out by utility providers, hence government and private institutions should invest in local research tailored towards reducing the cost of production of meters.

\section{Commitment and Responsible Outlook by Stakeholders}

Electricity theft, illegal connections, and tampering of electricity meters have been major problems in the electricity company (Osigwe and Chukwuemeka, 2018). To curb these, consumers should abide by the set rules and regulations of the industry to avoid unreliability, overloading of lines, and inappropriate increase in legal consumers' billings. NERC stated that the metering of electricity users is the responsibility of the DisCos however, financial incapability has made metering unsuccessful. The lack of commitment by the DisCos resulted in the non-implementation of the CAPMI policy and with the introduction of the MAP regulation, it was expected that DisCos and other stakeholders should be responsive to their responsibility so that meters will be available to electricity users. Utility providers should keep enumerating unmetered customers as stipulated by NERC and the customers should take advantage of all mediums made available to be enumerated. The government should subsidize electricity metering and installation to bring down the cost of meters rather than subsidizing electricity consumption tariffs. Also, complete enforcement of all the metering policies should be made.

\section{E. Training of Technical Personnel}

It has been observed that the lack of technological knowhow has grossly affected the deployment of smart meters and a weak distribution grids have made a smooth upgrade to a 
smart grid practically impossible. Therefore, partnerships with international companies with requisite technical know-how in smart meter development and deployment should be encouraged to allow technology transfer and skill acquisition to assist indigenous engineers with innovative ideas to achieve increased local content in electricity meter production.

\section{F. Meter Tampering and Swapping}

Electricity meter tampering can either be intrusive or nonintrusive. Intrusive meter tampering involves direct access to the meter by removing the meter case and then modify the components inside the meter while non-intrusive tampering occurs outside the meter (Mesganaw, 2018), Although, electricity meter manipulation and energy theft are aggravated because electricity consumers are not properly and appropriately metered (Shokoya and Raji, 2019). Electricity Distribution Companies (DisCos) in Nigeria suffer an N30,000 revenue deficit monthly due to theft and the government's fixed pricing policy (Nextier Power 2018). Electricity meter tampering and energy theft also contributed towards electricity metering evolution in Nigeria.

\section{FINDINGS AND DISCUSSION}

\section{A. Non-technical Solutions}

The literature review has shown that lack of policy implementation has contributed majorly to the unsuccessful implementation of metering of all electricity consumers. It is suggested that there is a need for the government to reappraise the performance of all stakeholders in the electricity sector in a bid to provide a framework that will bring about the realization of the reform objectives (Anyaehie and Iwuamadi, 2020). NERC has been criticized for its unwillingness to enforce its authority as a regulator on all stakeholders and in particular on the laxity of the DisCos in their non-compliance with the implementation of various policies that will ensure electricity consumers are metered. As it is observed in the review that one of the major objectives of the reform is to ensure the consumers are billed commensurate with their consumption, it is regrettable to say that arbitrary billing is still prevalent because the electricity consumers are without the critical prepaid meters that will ensure proper billing but the respective DisCos do not have the financial withal to fund massive electricity meter roll-out (Audu et al., 2017).

The MAP policy implementation should be closely monitored because the quality and reliability of the prepaid meters can be compromised by third-party investors. In the study by Onyeoru (2019), most electricity customers are not metered, yet they receive exorbitant bills and the notion that payment will be exerted from the customers encourages the utility not to prioritize the issue of electricity metering of customers. Efforts need to be intensified to make electricity meters available to all customers. The high cost of smart metering technology in comparison with prepaid metering has discouraged its roll-out by the utility. The cost of electricity meters is beyond the reach of average electricity users.

The government should as a matter of urgency set a policy on electricity metering of all household, that would span several years due to the high number of people that are not metered and also those that do not have access to electricity, with funds appropriated for the meter roll-out and remove subsidy on electricity consumption has it is presently done. This policy should look towards cost-effective metering devices and infrastructure due to the earning capacity of the average Nigerians and employ the prepaid smart system to ensure revenue collection by the utility.

The MAP policy initiated by the Government and regulatory agency should also be aggressively pursued with an adequate oversight on the quality of the prepaid meters to be installed. Policymakers should avoid the infiltration of personal interest in the course of implementation of policies to achieve the intended aim for which the policy is formulated (Idowu et al., 2019). Personal interest should be discountenanced in policymaking and implementation to ensure that technical know-how and financial capability which are criteria for due process are not jettisoned. Cost reflective tariffs which have been a contending issue between the utility and customers will become irrelevant when the customers are metered and appropriately billed.

\section{B. Technical Solutions}

Electricity theft remains a huge loss incurred by electricity distribution companies. This theft arises majorly because of activities carried out by consumers such as energy-meter bypassing, energy-meter tampering, etc. Shokoya and Raji, (2019) stated that the DisCos lose about 30 billion every month owing to electricity theft. This amount can significantly affect negatively the evolution of metering in Nigeria.

In addressing this phenomenon, the earliest technical solution introduced by the DisCos was the use of locks and tamper-evident seals which provide physical detection of manipulation of a meter when physically inspected but it does not achieve deterrence from offenders. A split metering solution was later introduced as a better solution in overcoming the problem of energy theft and tampering. This involves the splitting of the metering device such that the meter and power connection point are located outside the customer premises with an interface of the display panel and integrated keyboard provided at the customer premises.

Many researchers have proposed different methods of overcoming these non-technical losses via methods ranging from the inclusion of sensors to using machine learning or artificial intelligence algorithms. (Malhotra and Seethalakshmi, 2013) proposed two phases of theft control using embedded systems which were named tampering of seal in energy meter and underground power theft control. For detecting the tampering of the seal, an IR sensor is mounted in the energy meter screw with a $12 \mathrm{v}$ rechargeable battery. After detecting the theft, the IR sensor transmits the information to the PIC microcontroller, which then sends a message to the government office via GSM. (Mohammad et al., 2013) suggested a prepaid electricity metering scheme to deter power theft. At the consumer's device, a single-phase smart meter is mounted, which communicates with a public utility server. Like in (Malhotra and Seethalakshmi, 2013) a GSM module was mounted in each meter and server to allow bi-directional communication between the smart meter and the server. An ATmega 32 microcontroller, ADE7751 energy measuring 
chip, Siemens A62 cell phone as the GSM module, MAX232, current transformer (CT-1) and potential transformer (PT-1) used for current and voltage measurements, LCD, and a relay were used in this project's energy metering devices.

Dineshkumar et al., (2015) also proposed using a configuration with an LPC1343, ARM processor, ACS712 30A range current sensor, potential transformer with fourterminal controlled power supply, GSM module for contact, lever switch, and 200W AC load in this paper. The technique of theft detection adopted by this system is very similar to the method used. The major difference here is the use of the fourterminal output regulated potential transformer instead of using two potential transformers. One of the four terminals of the power supply is directly connected to the energy meter, while the other three are limited to $3.3 \mathrm{~V} \mathrm{DC}$. One of the three controlled DC voltages is fed to the ARM processor's interrupt pin to detect the whole meter bypassing, while the other two terminals are used to charge the battery that powers the GSM module and the ARM processor.

Different from hardware solutions, (Khan et al., 2020) in Electricity Theft Detection Using Supervised Learning Techniques on Smart Meter Data suggested a software approach using Machine learning/ Artificial Intelligence. (Khan et al., 2020) stated that interpolation, the three-sigma law, and normalization methods are used to pre-process the electricity results. Since the distribution of labels in the electricity consumption data is distorted, the problem is solved using the Adasyn algorithm. The balanced data is then fed into a Visual Geometry Group (VGG-16) module, which looks for irregular trends in electricity consumption. Finally, for classification, a Firefly Algorithm-based Extreme Gradient Boosting (FA-XGBoost) technique is used.

\section{Recent Effort by the Government to Increase Meter Penetration}

The National Assembly in 2019 introduced the Electric Power Sector Reform Act (EPSRA) (Amendment) Bill of 2019 to prohibit and criminalize estimated billing with associated tariffs to enforce the deployment of electricity meters by the Discos. The reluctance by Discos to effectively engage MAP providers to achieve massive metering of the electricity customers led to the order on capping of estimated billing enshrined in Order No/NERC/197/2020, which took effect from $20^{\text {th }}$ February 2020 as a result of previous and current efforts of the regulator to ensure the Discos supply meters to their customers (Olalere, 2020). The Order No/NERC/197/2020 was to replace the Nigerian Electricity Regulatory Commission (Methodology on Estimated Billing) Regulation of 2012 to achieve compliance with massive meter roll-out.

The Federal Government of Nigeria introduced the National Mass Metering Program (NMMP) in October 2020 as policy support to the implementation of MAP regulation. The combined effect of the regulatory and policy implementation is set to achieve rapid deployment of meters to electricity consumers (Bungane, 2021). The NMMP policy is to provide a loan facility to the Discos and local meter manufacturers (Aderemi et al., 2021). It is expected that the NMMP policy will provide six million meters within 18-24 months and impact an estimated 30 million electricity consumers nationwide (Olatunji, 2020)._Free delivery of electricity meters was part of the agreement reached between the Federal Government and the organized labour (National Labour Congress) after the government raised the electricity tariff (Agbakwuru, 2020).

The Federal Government commenced the NMMP on the $29^{\text {th }}$ of October 2020, distributing six million free prepaid electricity meters to Nigerians in the franchise areas of Eko, Kano, Kaduna, and Ikeja Distribution Companies (DisCos). The NMMP would boost Nigeria's metering rate, reduce estimated billing, and improve the local meter value chain by growing local meter production, assembly, and deployment capability. The program would also minimize collection losses, increase financial flows to ensure DisCos meet their $100 \%$ consumer remittance obligations and aid Nigeria's economic recovery by creating employment in the local meter supply chain while also ensuring consumers pay the exact price for their energy usage. (Olatunji, 2020). Apart from its job creation potentials in the Meter value chain, the program will further strengthen the local meter value chain by increasing local meter manufacturing, assembly, and deployment capacity, all in support of Nigeria's economic recovery plan. (iedisco, 2020).

Following Mr. President's mass metering directive, the Central Bank of Nigeria approved guidelines for funding the mass metering program on October $18^{\text {th, }} 2020$ requiring that all meters under the scheme be locally sourced, resulting in the creation of thousands of manufacturing jobs through lead manufacturers such as MOMAS, MOJEC, and others. The NMMP will be introduced as part of a continuous initiative in which all DisCos will collaborate with their respective Meter Asset Providers to install meters for all Nigerians across the country (Agbakwuru, 2020).

The rolling out of these meters is proposed to be in 3 phases. In the first phase, there will direct financing of all meters ready for quick deployment, including meters at the ports, those incountry available stock, committed orders by MAPs between September 2020 and April 2021. While In the second phase, the CBN financing and procurement targeted exclusively at local manufacturers and assemblers will be concluded in the fourth quarter of 2021. And then the last phase would be the World Bank International procurement, which gives a 20percent buffer allowance to local manufacturers to order to improve their competitiveness and encourage joint ventures with local companies by December 2022. According to (Sundiatapost, 2020), The project is expected to cost about $\$ 405$ million and the World Bank is providing \$200 million while the CBN will provide the balance of $\$ 205$ million. The World Bank will spend the $\$ 200$ million bulk procurement of meters under the proposed Nigeria Distribution Sector Recovery Program. The World Bank bulk meter procurement would be a loan to the Federal Government to be paid back by electricity customers and the Federal Government.

\section{CONCLUSION}

Electricity metering in Nigeria is evolving but with the journey so far, more is still required to be done by all stakeholders to ensure the metering of all electricity consumers 
and make electricity meters available and affordable. The various DisCos should have a common framework guiding the implementation of electricity metering so that in the long run, the distribution grid could eventually be transitioned into a smart distribution grid. Innovative ideas in low-cost meter design technology in the Nigerian technological space should be supported for standardization and mass production for eventual deployment in Nigeria. The government has begun to make special intervention in the electricity supply industry especially concerning metering because finance has been repeatedly echoed as a factor that has made metering electricity users impossible. Future research will continue to investigate the penetration of meters in Nigeria and with the new initiative of the government, the metering evolution is expected to be faster, the metering penetration broader and customer satisfaction greater.

\section{ACKNOWLEDGEMENT}

This research is funded by Tertiary Education Trust Fund 2019 (TETFund/DR\&D-CE/NRF/2019)

\section{REFERENCES}

Abdulwahab, L. (2009). An Assessment of billing electricity consumers via analoque meters in Kano, Nigeria, by Kano Electricity Distribution plc. Bayero Journal of Pure and Applied Sciences, 2(1): 27 - 33.

https://doi.org/10.4314/bajopas.v2i1.58451

Adekitan, I. A.; B. Adetokun; A. Aligbe; T. Shomefun and A. Orimogunje (2018). Data-Based Investigation of the Energy Metering Type, Billing and Usage of Sampled Residents of Ota Community in Nigeria. Data in Brief, 20: 159-172. https://doi.org/10.1016/j.dib.2018.07.047

Aderemi, T.; O. Afonja and I. Umoh (2021). Nigeria: National Mass Metering Programme (NMMP) . Retrieved from Mondaq Ltd: https://www.mondaq.com/nigeria/government-contractsprocurement-ppp/1024824/national-mass-metering-

programme-nmmp

Adetoba, B.; N. Yekini; O. Lawal and H. Alakiri (2018). Enhancing Billing and Minimization of Electricity Theft in the Electrical Power Distribution via ICT. SMART-iSTEAMS Multidisciplinary Conference: 95-106. Ogwuashi-uku, Delta State, Nigeria.

Adetokun, B.; T. Somefun; A. Aligbe and A. Orimogunje (2018). Development of an ANN-based Estimated Electricity Billing System. IEEE PES/IAS PowerAfrica: 96-101. Abuja: IEEE. https://doi.org/10.1109/PowerAfrica.2018.8521004

Agbakwuru, J. (2020). FG Begins Nationwide Distribution of 1M Free Meters in Kano, Kaduna, Lagos. Retreived from Vanguard Nigeria, October 20, 2020 https://www.vanguardngr.com/2020/10/fg-beginsnationwide-distribution-of- $1 \mathrm{~m}$-free-meters-in-kano-kadunalagos/

Ajenikoko, G. A. and Adelusi, L. O. (2015). Impact of Prepaid Energy Metering System on the Electricity Consumption in Ogbomoso South Local Government Area of Oyo State. Journal of Computer Engineering and Intelligent Systems, 6(5): 99-105.
Akpan, A. G.; M. Shedrack and B. Barida (2019). Smart Metering Intelligent Systems: A Panacea for Efficient Energy Management in Nigeria. Restaurant Business, 15(67): 62-67.

Akwuiwu, I.; D. Okolo and R. Okonigene (2018). Automated Electricity Power Metering System. Int'l Conf. Wireless Networks: 55-59. CSREA Press.

Aliu, I. (2020). Energy Efficiency in Postpaid-Prepaid Metered Homes: Analyzing Effects of Socio-Economic, Housing, and Metering Factors in Lagos, Nigeria. Energy Efficiency, 13: 853-869. https://doi.org/10.1007/s12053-020-09850-y

Amakom, U. and Nwogwugwu, U. C. (2012). Financing Energy Development in Nigeria: Analysis of Impact on the Electricity Sector. Australian Journal of Business and Management Research, 2(3): 54-61.

Amhenrior, H. (2018). An Assessment of Consumers' Experiences and the Desired Improvements on the use of the Existing Prepayment Meters in Parts of Benin City and Warri in Nigeria. Nigerian Research Journal of Engineering and Environmental Sciences, 3(2): 857-867.

Amhenrior, H.; F. Edeko; E. Ogujor and J. Emagbetere (2017). Design and Implementation of an Automatic Tamper Detection and Reporting Capability for a single-phase Energy Meter. 2017 IEEE 3rd International Conference on ElectroTechnology for National Development (NIGERCON): 802$811 . \quad$ Owerri, Nigeria: https://doi.org/10.1109/NIGERCON.2017.8281947

Aniedu, A.; H. Inyiama and A. Azubogu (2017). Smart Meters and Advanced Metering Infrastructure: Panacea to Nigeria's Billing and Monitoring Problem. Journal of Engineering and Applied Sciences, 2(1): 1-14.

Anyaehie, M. and Iwuamadi, O. (2020). Electricity Privatization in Nigeria: Issues and Challenges. IOSR Journal of Electrical and Electronics Engineering (IOSR-JEEE), 15(1): 1-9. DOI: 10.9790/1676-1501010109

Anyaehie, M.; S. Nwadike and O. Iwuamadi (2018). The Implications of Estimated Billing System on Nigerian Electricity Consumers. American Journal of Engineering Research (AJER), 7(4): 169-175.

Arawomo, D. F. (2017). Electricity billing systems and household electricity use behaviour in Ibadan, Nigeria. Energy for Sustainable Development, 40: 77-84. https://doi.org/10.1016/j.esd.2017.07.004

Arimoro, T.; A. Oyetunji and Odugboye, O. (2019). Analysis of Electricity Billing System in Corporate Buildings in Lagos, Nigeria. Journal of Management and Economic Studies, 1(6): 10-20. doi:10.26677/TR1010.2019.150. https://doi.org/10.26677/TR1010.2019.150

Arowolo, W. and Perez, Y. (2020). Market Reform in the Nigeria Power Sector: A Review of the Issues and Potential Solutions. Energy Policy, 144: 1-30. https://doi.org/10.1016/j.enpol.2020.111580

Audu, E.; S. O. Paul and A. Ameh (2017). Privatisation of Power Sector and Poverty of Power Supply in Nigeria: A Policy Analysis. International Journal of Development and Sustainability, 6(10): 1218-1231.

Ayamolowo, O.; E. Buraimoh; A. Salau and J. Dada (2019). Nigeria Electricity Power Supply System: The Past, Present and the Future. IEEE PES/IAS Power Africa: 64-69. 
Abuja,

Nigeria:

https://doi.org/10.1109/PowerAfrica.2019.8928767

Ayamolowo, O.; A. Salau and Wara, S. (2019). The Power Industry Reform in Nigeria: The Journey So Far. IEEE PES/IAS Power Africa (pp. 12-17). Abuja, Nigeria: IEEE. https://doi.org/10.1109/PowerAfrica.2019.8928657

Bimenyimana, S. and Asemota, G. N. (2018). Traditional Vs Smart Electricity Metering Systems: A Brief Overview. Journal of Marketing and Consumer Research, 46: 1-7.

Bungane, B. (2021). NERC Tables an Order on The Replacement of Obsolete Meters. Retrieved from www.esiafrica.com: https://www.esi-africa.com/industrysectors/metering/nerc-tables-an-order-on-the-replacement-ofobsolete-meters/

Chiatula, C.; B. Saka; T. Sadiq; S. Adeshina; and Tsado, J. (2019). The Smart Way. IEEE PES/IAS PowerAfrica: 353-356. Abuja: IEEE. https://doi.org/10.1109/PowerAfrica.2019.8928642

Chukwuorji, O. V.; B. Saka; I. D. Inuwa; S. U. Hussein; S. Thomas and S. A. Adeshina (2019). Smart Grid and Distributed Generation: A Panacea for Nigeria's Power Problems. IEEE PES/IAS PowerAfrica: 357-361. Owerri: IEEE.

https://doi.org/10.1109/PowerAfrica46609.2019.9078672

Dada, J. O. (2014). Towards Understanding the Benefits and Challenges of Smart/Micro-Grid For Electricity Supply system in Nigeria. Renewable and Sustainable Energy Reviews, 38: 1003-1014. https://doi.org/10.1016/j.rser.2014.07.077

David, N. (2018). The Effect of Energy Theft on Climate Change and its Possible Prevention using Smart Meters: Case Study Nigeria. International Journal of Scientific and Engineering Research, 9(1): 1775-1779.

Dineshkumar, K.; P. Ramanathan and Ramasamy, S. (2015). Development of ARM Processor-Based Electricity Theft Control System using GSM network. IEEE International Conference on Circuit, Power and Computing Technologies, ICCPCT

2015. https://doi.org/10.1109/ICCPCT.2015.7159401

Diji, C. (2013). A Critical Review of the Nigerian Energy Scenario. IOSR Journal of Electrical Electronics Engineering (IOSR-JEE):

$55-63$. https://doi.org/10.9790/1676-535567

Dike, D. O.; U. A. Obiora; E. C. Nwokorie and B. C. Dike (2015). Minimizing Household Electricity Theft in Nigeria Using GSM Based Prepaid Meter. American Journal of Engineering Research (AJER), 4(1): 59-69.

Dike, D. O.; G. E. Ogu; N. Chukwuchekwa and B. C. Dike. (2017). Improving Distribution System Performance in Deregulated Electricity Industry Using Phase-Constrained Billing Scheme. IOSR Journal of Electrical and Electronics Engineering (IOSR-JEEE), 12(2): $\quad 80-87$. https://doi.org/10.9790/1676-1202018087

Ebem, D.; U. Arinze; U. Okebanama and C. Ebem (2018). An Optimized Web-Based Energy Billing System for Electricity Consumers in Nigeria. Advances in Multidisciplinary and Scientific Research, 4(3): 53-64. https://doi.org/10.22624/AIMS/V4N3P7
Ejumudo, T. F. and Ejumudo, K. B. (2014). The Operations of the Power Holding Company of Nigeria and Discriminatory Monopoly. Journal of Energy Technologies and Policy, 4(6): 60-68.

Elizabeth, A.; W. Samuel; A. Felix and Simeon, M. (2018). Smart Grid Technology Potentials in Nigeria: an Overview. International Journal of Applied Engineering Research, 13(2): 1191-1200.

Emodi, N. V. and Yusuf, S. D. (2015). Improving Electricity Access in Nigeria: Obstacles and the Way Forward. International Journal of Energy Economics and Policy, 5(1): 335-351.

Fagbohun, O. O. and Femi-Jemilohun, O. (2017). Prepaid Metering Empowerment for Reliable Billing and Energy Management of Electricity Consumers in Nigeria. Journal of Scientific Research and Reports, 17(2): 1-13. DOI: 10.9734/JSRR/2017/36344 https://doi.org/10.9734/JSRR/2017/36344

Fidelis, C. D.; C. J. Amadi; and H. O. Agbata (2019). Abating Electrical Power Theft in Nigeria Using Smart Meters and Data Analysis. ResearchGate. https://www.researchgate.net/publication/330159303_Abatin g_Electrical_Power_Theft_In_Nigeria_Using_Smart_Meters _And_Data_Analysis

iedisco. (2020). Launch of National Mass Metering Programme by Ikeja Electric | Ikeja Electric. https://www.ikejaelectric.com/launch-of-national-massmetering-programme-by-ikeja-electric/

Idowu, S. S.; J. Ibietan and Joshua, S. (2020). Debureaucratization of Power in Nigeria. A. Farazmand (ed.), Global Encyclopaedia of Public Administration, Public Policy, and Governance: 1-5. doi:10.1007/978-3-319-31816-5_39741 https://doi.org/10.1007/978-3-319-31816-5_3974-1

Idowu, S. S.; J. Ibietan and Olukotun, A. (2019). Nigeria's Electricity Power Sector Reform: An Appraisal of Unresolved Issues. International Journal of Energy Economics and Policy, 9(6): 336-341. https://doi.org/10.32479/ijeep.8232

Idowu, S. S.; J. Ibietan and A. Olukotun (2019). Political Considerations and Performance of Ibadan and Ikeja Electricity Distribution Companies in Nigeria's Power Sector Reforms: An Empirical Interrogation. Proceedings of INTCESS 2019- 6th International Conference on Education and Social Sciences, 381-389. Dubai, U.A.E.

Idowu, S. S.; J. Ibietan and A. Olukotun (2019). Privatization of Power Sector in Nigeria: An Evaluation of Ibadan and Ikeja Electricity Distribution Companies Performance (2005-2018). International Journal of Public Administration, 1-8. doi:10.1080/01900692.2019.1672183. https://doi.org/10.1080/01900692.2019.1672183

Iloh, J. (2020). Rogowski Coils for Design of Energy Meters for Nigeria Power Market. European Journal of Engineering Research and Science, 5(6): 626-631. https://doi.org/10.24018/ejers.2020.5.6.1827

Isola, W. and Mesagan, E. (2017). Electricity Affordability and Household Welfare in Nigeria. Journal of Economics and Business Research, 23(2): 59-74.

Jeremiah, K. (2020). Why-subsidy-in-power-sector-isunsustainable. Retrieved from the guardian.ng: 
https://guardian.ng/business-services/why-subsidy-in-powersector-is-unsustainable/

Jibril, K. A. (2017). Need for steady electricity in Nigeria. Retrieved from thenigerianvoice.com: www.thenigerianvoice.com/news/252000/need-for-a-steadyelectricity-in-nigeria.html

Jonathan, O.; A. Azeta and S. Misra (2018). Development of Prepaid Electricity Payment System for a University Community Using the LUHN Algorithm. In M.F. Kebe C.; Gueye A.; Ndiaye A. (eds) Innovation and interdisciplinary Solutions for Undeserved Areas. CNRIA 2017, Intersol 2017, Lecture Notes of the Institute of Computer Science, Social Informatics and Telecommunications Engineering, 204, Springer, Cham. https://doi.org/10.1007/978-3-319-72965-7_9

Kambule, N.; K. Yessoufou and N. Nwulu (2018). A Review and Identification of Persistent and Emerging Prepaid Electricity Meter Trends. Energy for Sustainable Development, 43: 173-185. https://doi.org/10.1016/j.esd.2018.01.007

Khan, Z. A.; M. Adil; N. Javaid; M. N. Saqib; M. Shafiq and J. G. Choi (2020). Electricity Theft Detection Using Supervised Learning Techniques on Smart Meter Data. Sustainability (Switzerland), 12(19): 1-25. https://doi.org/10.3390/su12198023

Komolafe, O. and Udofia, K. (2020). Review of Electrical Energy Losses in Nigeria. Nigerian Journal of Technology (NIJOTECH), $\quad 39(1)$ : $246-254$. https://doi.org/10.4314/njt.v39i1.28

Makanjuola, N.; O. Shoewu; L. Akinyemi and Y. Ajose (2015). Investigating the Problems of Prepaid Metering Systems in Nigeria. The Pacific Journal of Science and Technology, 16(2): 22-31.

Makanjuola, N.; O. Shoewu; L. Akinyemi and $O$. Ogunsanya (2019). Investigation on Smart Meters and Revenue Generated for a Year Using Eko Electricity Distribution Company of Nigeria as Case Study. Data Research, 3: 1-12.

Malhotra, R. P. and Seethalakshmi, R. (2013). Automatic Meter Reading and Theft Control System by Using GSM. International Journal of Engineering and Technology, 5(2): 806-810.

Matthews, V. O.; A. I. Adekitan; U. S. Idiake and E. Noma-Osaghae (2018). Wireless Intelligent Electricity Metering and Billing System (WIMBIS). International Journal of Engineering and Techniques, 4(4): 57-61.

Mohammad, N.; A. Barua and M. A. Arafat (2013). A Smart Prepaid Energy Metering System To Control Electricity Theft. Proceedings of 2013 International Conference on Power, Energy and Control, ICPEC 2013, ATmega 32: 562 565. https://doi.org/10.1109/ICPEC.2013.6527721

Monyei, C. G.; A. O. Adewumi; M. O. Obolo and B. Sajou (2017). Nigeria's Energy Poverty: Insights and Implications for Smart Policies and Framework Towards a Smart Nigeria Electricity Network. Renewable and Sustainable Energy Reviews, $\quad 81(1)$ : 1582-1601. https://doi.org/10.1016/j.rser.2017.05.237

Ndinechi, M.; O. Ogungbenro and K. Okafor (2011). Digital Metering System: A better Alternative for
Electromechanical Energy Meter in Nigeria. International Journal of Academic Research, 3(5): 189-193.

Niyonteze, J. D.; F. Zou, and G. N. Osarumwense (2019). Solar-Powered Mini-Grids and Smart Metering Systems, the Solution to Rwanda Energy Crisis. Journal of Physics: Conference Series 1311 012002: 1-10. https://doi.org/10.1088/1742-6596/1311/1/012002

Nwokoye, E., S. Dimnwobi; C. Ekesiobi and C. Obegolu (2017). Power Infrastructure and Electricity in Nigeria: Policy Consideration for Economic Welfare. KIU Journal of Humanities, 2(1): 5-17. https://doi.org/10.6007/IJAREMS/v5-i3/2242

Odutola, A. (2019). Over 100 million Nigerians Earn Less Than N700 Daily - UK's EFInA. Retrieved from nairametrics.com: https://nairametrics.com/2019/12/09/over100-million-nigerians-earn-less-n700-daily-uks-efina/

Ogbuefi, U. C.; P. C. Ene and P. A. Okoro (2019). Prepaid Meter Tariffing for Actual Power Consumption in an Average Household: A Case Study of Nigeria DisCo. Nigerian Journal of Technology (NIJOTECH), 38(3): 750 - 755. https://doi.org/10.4314/njt.v38i3.29

Ogu, R. and Chukwudebe, G. (2017). Development of a Cost-Effective Electricity Theft Detection and Prevention System based on IoT Technology. IEEE 3rd International Conference on Electro-Technology for National Development (NIGERCON): 756-760. Owerri: IEEE. https://doi.org/10.1109/NIGERCON.2017.8281943

Ogujor, E. A. and Otasowie, P. O. (2010). The Impact of the Pre-Paid meter on Revenue Generation in Nigeria. The Pacific Journal of Science and Technology, 11(1): 138-142.

Okafor, K.; G. Ononiwu; J. Okoye and M. Ndubuaku (2017). Enterprise Energy Analytic Cloud Metering Portal for On-Demand Service Provisioning. Indian Journal of Science and Technology, 10(36): 1-13. https://doi.org/10.17485/ijst/2017/v10i36/111913

Okafor, K.; G. Ononiwu; J. Okoye and M. Ndubuaku (2017). Enterprise Energy Analytic Cloud Metering Portal for On-Demand Service Provisioning. Indian Journal of Science and Technology, 10(36): 1-13. https://doi.org/10.17485/ijst/2017/v10i36/111913

Okolobah, V. and Ismail, Z. (2013). On the Issues, Challenges, and Prospects of Electrical Power Sector in Nigeria. International Journal of Economy, Management and Social Sciences, 2(6): 410-418.

Okoro, O. I. and Chikuni, E. (2007). Power sector reforms in Nigeria: Opportunities and Challenges. Journal of Energy in Southern Africa, 18(3): 52-57. https://doi.org/10.17159/2413-3051/2007/v18i3a3386

Olalere P. O (2020). Recent Order on the Capping of Estimated Bills in the Nigerian Electricity Supply Industry: A Timely Regulatory Scale-Balancing Order. https://www.mondaq.com/nigeria/oil-gas-

electricity/923040/recent-order-on-the-capping-of-estimatedbills-in-the-nigerian-electricity-supply-industry-a-timelyregulatory-scale-balancing-order. $6^{\text {th }}$ April, 2020.

Olaoluwa, O. G. (2017). Electricity Theft and Power Quality in Nigeria. International Journal of Engineering Research and Technology (IJERT), 6(06): 1180-1184.

Olatunji, K. (2020). FG commences distribution of free 
Pre-Paid Electricity Meters | The Guardian Nigeria News Nigeria and World NewsNigeria - The Guardian Nigeria News - Nigeria and World News. https://guardian.ng/news/fgcommences-distribution-of-free-pre-paid-electricity-metres/

Oluwatoyin, K.; A. Odunola and A. Alabi (2015). Ways of Achieving Stable and Uninterrupted Power Supply of Electricity in Nigeria. British Journal of Applied Science and Technology, 10(5):

$1-15$. https://doi.org/10.9734/BJAST/2015/17043

Omijeh, B.; G. Ighalo and F. Anyasi (2012). Intelligent Power Theft Detection Model for Prepaid Energy Metering In Nigeria. International Journal of Electronics Communication and Computer Engineering, 3(6): 1366-1371.

Onochie, U.; H. Egware and T. Eyakwanor (2015). The Nigeria Electric Power Sector (Opportunities and Challenges). Journal of Multidisciplinary Engineering Science and Technology (JMEST), 2(4): 494-502.

Onyeoru, H. (2019). Measurement and Evaluation of Bills Sent by Power Utility Companies to Consumers of Electricity in Nigeria. Journal of Appl. Sci. Environ. Manage, 23(4): 769773. https://doi.org/10.4314/jasem.v23i4.31

Orovwiroro, G. (2019). Meter Asset Provider (MAP) Intervention Program and Bridging the Metering Gap in the Power Sector: Rivers State Experience, Nigeria. EPRA International Journal of Research and Development (IJRD), 4(3): 22-29.

Orukpe, P. E., and Agbontaen, F. O. (2013). Prepaid Meter in Nigeria: The Story so Far and the Way Forward. Advanced Materials Research, 824: 114-119. https://doi.org/10.4028/www.scientific.net/AMR.824.114

Oseni, M. O. (2012). Improving Households' Access to Electricity and Energy Consumption Pattern in Nigeria: Renewable energy alternative. Renewable and Sustainable Energy, $\quad 16(6)$ : 3967- 3974. https://doi.org/10.1016/j.rser.2012.03.010

Oseni, M. O. (2015). Assessing the consumers' willingness to adopt a prepayment metering. Renewable and Sustainable Energy, 86: 154-165. https://doi.org/10.1016/j.enpol.2015.06.038

Osigwe, A. and Onyimadu, C. (2018). Electricity Theft in Nigeria: How Effective are the Existing Laws? Journal of Energy Technologies and Policies, 8(8): 8-13.

Oyedepo, S. O. (2012). Efficient Energy Utilization as a Tool for Sustainable Development in Nigeria. International Journal of Energy and Environmental Engineering, 3(11): 112.

https://doi.org/10.1186/2251-6832-3-11

Oyedepo, S. O. (2012). On energy for sustainable development in Nigeria. Renewable and Sustainable Energy Reviews, 16 : 2583-2598. https://doi.org/10.1016/j.rser.2012.02.010

Qazi, U.; S. Iqbal.; H. Zaheer and R. T. Ur (2020). Prepaid metering: A Way Forward for The Sustainable Power Sector in Pakistan. Energy Strategy Reviews, 31: 1-10. https://doi.org/10.1016/j.esr.2020.100546
PricewaterhouseCoopers (PWC) (2019). Solving the Liquidity Crunch in the Nigerian Power Sector. White Paper presented at Power Sector Roundtable Conference hosted by Mainstream Energy Solutions Limited on September 24, 2019, at Kainji Dam Hydropower Plant, Niger State

Shokoya, N. and Raji, A. (2019). Electricity Theft Mitigation in The Nigerian Power Sector. International Journal of Engineering and Technology, 8(4): 467-472.

Smart Energy International. (2014). Metering Africa: Nigeria Approves 138 Metering Service Providers. Retrieved from www.smart-energy.com: https://www.smartenergy.com/regional-news/africa-middle-east/meteringafrica-nigeria-approves-138-metering-service-providers/

Somefun, T.; C. Awosope and A. Chiagoro (2019). Smart prepaid energy metering system to detect energy theft with facility for real-time monitoring. International Journal of Electrical and Computer Engineering (IJECE), 5: 4184-4191. https://doi.org/10.11591/ijece.v9i5.pp4184-4191

Sule, A. (2010). Major Factors Affecting Electricity Generation, Transmission, and Distribution in Nigeria. International Journal of Engineering and Mathematical Intelligence, 1(1and3): 159-164. Retrieved December 12, 2020

Sundiatapost. (2019). Distribution of 900,000 free Electricity Meters Begins Today in Lagos, Kano, Kaduna Nigerian Investment Promotion Commission. https://nipc.gov.ng/2020/10/30/distribution-of-900000-freeelectricity-meters-begins-today-in-lagos-kano-kaduna/

Ugonna, E. E.; A. K. Ademola and A. T. Olusegun (2018). Design and Construction of a Smart Electric Metering System for Smart Grid Applications: Nigeria as a Case Study. International Journal of Scientific and Engineering Research, 9(7): 798-805.

Unachukwu, G. O. (2010). Energy Savings Opportunities at the University of Nigeria, Nsukka. Journal of Energy in Southern Africa, 21(1): 2-10. https://doi.org/10.17159/24133051/2010/v21i1a3244

Usman, A. (2013). Determinants of Electricity Consumers Satisfaction in Selected Electricity Distribution Zones in Nigeria: Implications for Regulatory Activities. Journal of Asian Business Strategy, 3(6): 103-124.

Usman, D. J.; N. Yaacob and A. A. Rahman (2016). Scale Development for Consumer Protection and its Determinants: Evidence from Nigeria. International Journal of Law and Management, 58(4): 1-19. https://doi.org/10.1108/IJLMA-04-2015-0018

Usman-Hamza, F. and Salau-Ibrahim, T. (2016). Development of a Business Intelligence Portal Framework in a Cloud Computing Environment for Enhanced Distribution and Billing System of Electricity in Nigeria. Advances in Multidisciplinary and Scientific Research, 2(1): 79-86.

Utazi, D. N. and Obuka, N. S. (2014). Inadequate and Poor Electricity Metering Affect Inadequate and Poor Electricity Metering Affect. International Journal of Engineering Trends and Technology (IJETT), 12(8): 371-377. https://doi.org/10.14445/22315381/IJETT-V12P272 